\title{
Are ant assemblages of Brazilian veredas characterised by location or habitat type?
}

\author{
Costa-Milanez, CB. ${ }^{\mathrm{a}, \mathrm{b} *}$, Lourenço-Silva, G. ${ }^{\mathrm{a}, \mathrm{b}}$, Castro, PTA. ${ }^{\mathrm{a}}$, Majer, JD. ${ }^{\mathrm{c}}$ and Ribeiro, SP. ${ }^{\mathrm{b}}$ \\ ${ }^{a}$ Department of Geology, Universidade Federal de Ouro Preto - UFOP, Campus Morro do Cruzeiro, s/n, Bauxita, \\ CEP 35400-000, Ouro Preto, MG, Brazil \\ ${ }^{b}$ Laboratory of Evolutionary Ecology of Canopy Insects and Natural Succession, Department of Biodiversity, \\ Evolution and Environment, Instituto de Ciências Exatas e Biológicas - ICEB, Universidade Federal de Ouro Preto - UFOP, \\ Campus Morro do Cruzeiro, s/n, Bauxita, CEP 35400-000, Ouro Preto, MG, Brazil \\ ${ }^{\mathrm{c}}$ Curtin Institute for Biodiversity and Climate, Curtin University, PO Box U1987, Perth, WA 6845, Australia \\ *e-mail: cborgesdacosta@gmail.com
}

Received: August 21, 2012 - Accepted: January 8, 2013 - Distributed: February 28, 2014

(With 4 figures)

\begin{abstract}
Wetland areas in the Brazilian Cerrado, known as "veredas", represent ecosystems formed on sandy soils with high concentrations of peat, and are responsible for the recharge of aquiferous reservoirs. They are currently under threat by various human activities, most notably the clearing of vegetation for Eucalyptus plantations. Despite their ecological importance and high conservation value, little is known about the actual effects of human disturbance on the animal community. To assess how habitat within different veredas, and plantations surrounding them affect ant assemblages, we selected four independent vereda locations, two being impacted by Eucalyptus monoculture (one younger and one mature plantation) and two controls, where the wetland was surrounded by cerrado vegetation. Ant sampling was conducted in May 2010 (dry season) using three complementary methods, namely baits, pitfall traps, and hand collection, in the wetland and in the surrounding habitats. A total of 7,575 ants were sampled, belonging to seven subfamilies, 32 genera and 124 species. Ant species richness and abundance did not differ between vereda locations, but did between the habitats. When impacted by the monoculture, ant species richness and abundance decreased in wetlands, but were less affected in the cerrado habitat. Ant species composition differed between the three habitats and between vereda locations. Eucalyptus plantations had an ant species composition defined by high dominance of Pheidole sp. and Solenopsis invicta, while natural habitats were defined by Camponotus and Crematogaster species. Atta sexdens was strictly confined to native habitats of non-impacted "veredas". Eucalyptus monocultures require high quantities of water in the early stages, which may have caused a decrease in groundwater level in the wetland, allowing hypogeic ants such as Labidus praedator to colonise this habitat.
\end{abstract}

Keywords: mesic environments, bioindication, Formicidae, Brazilian savanna, Eucalyptus.

\section{Caracterização da assembleia de formigas (Hymenoptera: Formicedae) em veredas impactadas pela monocultura de Eucaliptus}

\begin{abstract}
Resumo
O ecossistema ribeirinho do Cerrado brasileiro, é conhecido como "vereda", e é formado em solos arenosos com altas concentrações de turfa, além de serem responsáveis pela recarga dos reservatórios dos aquíferos. Atualmente, as veredas estão sob ameaça de várias atividades humanas, especialmente a supressão da vegetação para plantio de Eucalyptus. Apesar de sua importância ecológica e elevado valor na conservação, pouco se sabe sobre os efeitos das perturbações humanas sobre a comunidade de animais. Para avaliar como que habitats em diferentes veredas e as plantações circundantes afetam a assembleia de formigas, foram selecionadas quatro "veredas" independentes, sendo duas impactadas pela monocultura de eucalipto (uma jovem e uma madura) e duas controles com a planície de inundação circundada por vegetação de cerrado. A coleta das formigas foi realizada em Maio de 2010 (estação seca) por meio de três métodos complementares, iscas atrativas, armadilhas de pitfall e coleta direta, no habitat de planície alagada, e na área circundante. Foi amostrado um total de 7.575 formigas, pertencentes a sete subfamílias, 32 gêneros e 124 espécies. A riqueza e abundância de formigas não diferiram entre as localidades "veredas", mas sim entre os habitats. Quando impactados pela monocultura, a abundância e a riqueza diminuem nas planícies de inundação, mas os habitats de cerrado foram menos afetados. As plantações de eucalipto têm sua composição de espécies de formigas definida pela alta dominância de Pheidole sp. e Solenopsis invicta, enquanto os habitats naturais foram definidos por espécies de
\end{abstract}


Camponotus e Crematogaster. Atta sexdens foi estritamente relacionada à habitats nativos de "veredas" preservadas. A monocultura de eucalipto requer grandes quantidades de água nos estágios iniciais, o que pode ter provocado a queda no nível do lençol freático nas planícies alagadas, permitindo a colonização deste habitat por espécies de formigas de hábitos hipógeos, como Labidus praedator.

Palavras-chave: ambientes mésicos, bioindicação, Formicidae, savana brasileira, Eucalyptus.

\section{Introduction}

Brazilian cerrado is one of the most threatened Neotropical Biomes, suffering loss of biodiversity, invasion of exotic species, soil erosion, and pollution of aquifers (Oliveira-Filho and Lima, 2002). Embedded within the cerrado region, the "veredas" are wetland ecosystems formed on sandy soils with high concentrations of peat, and are responsible for recharge of aquiferous reservoirs; they are particularly endangered as a result of intensified human activity (Eiten, 1994; Alencar-Silva and Maillard, 2007). In addition to their hydrological, social, historical, cultural and economic importance, they are also considered to be of great importance for watershed conservation, which forms almost $80 \%$ of headwaters in the northwest of Minas Gerais. The soils are composed of very fine particle sizes, with large amounts of decaying organic matter, resulting in a black matter which is wet and colonised by hydrophilic grasses and the Buriti (Mauritia flexuosa L. f. - Arecaceae) palm tree.

The mesic characteristics of "veredas" make them important ecological corridors within the xeric environment, connecting fragments of cerrado and enabling several species populations gene flow to occur (Oliveira and Ferreira, 2007). Thus, when a moderately sized wetland is degraded, this can influence the degradation and possibly cause loss of integrity of hundreds of square kilometers of cerrado (Alencar-Silva and Maillard, 2007). One of the main causes of disorderly destruction of the cerrado is agribusiness, which had its beginning in the late 70's. Currently, planting of Eucalyptus is gaining nationwide interest due to the low investment cost and care, and growing market. There is still no consensus on the impacts of this type of monoculture on soil, groundwater and biodiversity, leading to intense debate between the scientific community and farmers' lobby groups, and also in the Brazilian Congress and Senate.

The "veredas" are areas protected under law due their environmental values, such as recharge of aquiferous reservoirs but, even so, tracts of these native areas are gradually being replaced by Eucalyptus plantations. Eucalyptus was introduced into Brazil at the end of the 19th century for the production of sleepers for railways lines (Mentone et al., 2011). Later, plantations were established for the paper industry. In their early stages, such plantations consume large amounts of water and nutrients (Vezzani et al., 2001; Vital, 2007), and in later stages the litter becomes rich in chemical compounds that slow down its degradation, leading to reduced cycling of nutrients and impoverishment of soil. The scale of these impacts in the veredas is not well understood, but is it in other cerrado phytophysiognomies (Marinho et al., 2002; Tavares et al., 2008). There is an urgent need for studies to assist with conservation measures and to help with the drafting of complementary laws that aim to protect this unique ecosystem in the light of novel land usage policies.

Soil fauna is an important component of such conservation studies, especially for understanding the soil dynamics and the fine-scale aspects of changes in soil features (Majer and Delabie, 1994; Majer et al., 2007), such as soil compaction and the associated lowering of groundwater, a typical problem caused by Eucalyptus monocultures (Vital, 2007). Ants, along with termites, worms, and certain other invertebrates, maintain the soil's intrinsic features. These invertebrates promote the formation of channels, pores, and aggregates that influence the transport of gases and water, and they also play important roles in geomorphology and soil formation (Coutinho et al., 2003; Lavelle et al., 2006). Because of their close connection with this stratum, ants are excellent indicators of soil quality (Costa et al., 2010).

The present study examined the assemblages of ant species in different vereda locations, which contain wetland habitats surrounded by cerrado habitats, or by lands where such vegetation has been replaced by Eucalyptus monoculture. We predicted that removal of native habitat (cerrado) to plant Eucalyptus may favour a few species belonging to generalist guilds, and possibly eliminate populations of rare or specialist species, thus decreasing species diversity.

\section{Material and Methods}

\subsection{Study area}

The veredas we studied are located in the northwest region of Minas Gerais state, in a typical cerrado region. The "veredas" are located in the municipalities of São

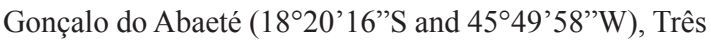
Marias (18 $15^{\circ} 12^{\prime \prime S}$ and $45^{\circ} 15^{\prime} 50^{\prime \prime} \mathrm{W}$ ) and Andréquicé (a district of Três Marias - 18²7'08.69"S and 044 50'51.12”'W (see Figure 1). The climate in the region of the high-mid San Francisco river basin is characterised Aw, according to Köppen's climatic divisions, being tropical and semihumid, with an average temperature of $24^{\circ} \mathrm{C}$, prevalent rainfall in summer (December until March), dry winters (July until September), and an average rainfall of 1,000 to $1,800 \mathrm{~mm}$.

The field work was carried out in two reasonably well preserved veredas (control locations): Curral das Éguas (Vereda P1) and Lagoa do Inferno (Vereda P2); and in two disturbed veredas (modified locations): Buriti (Vereda 


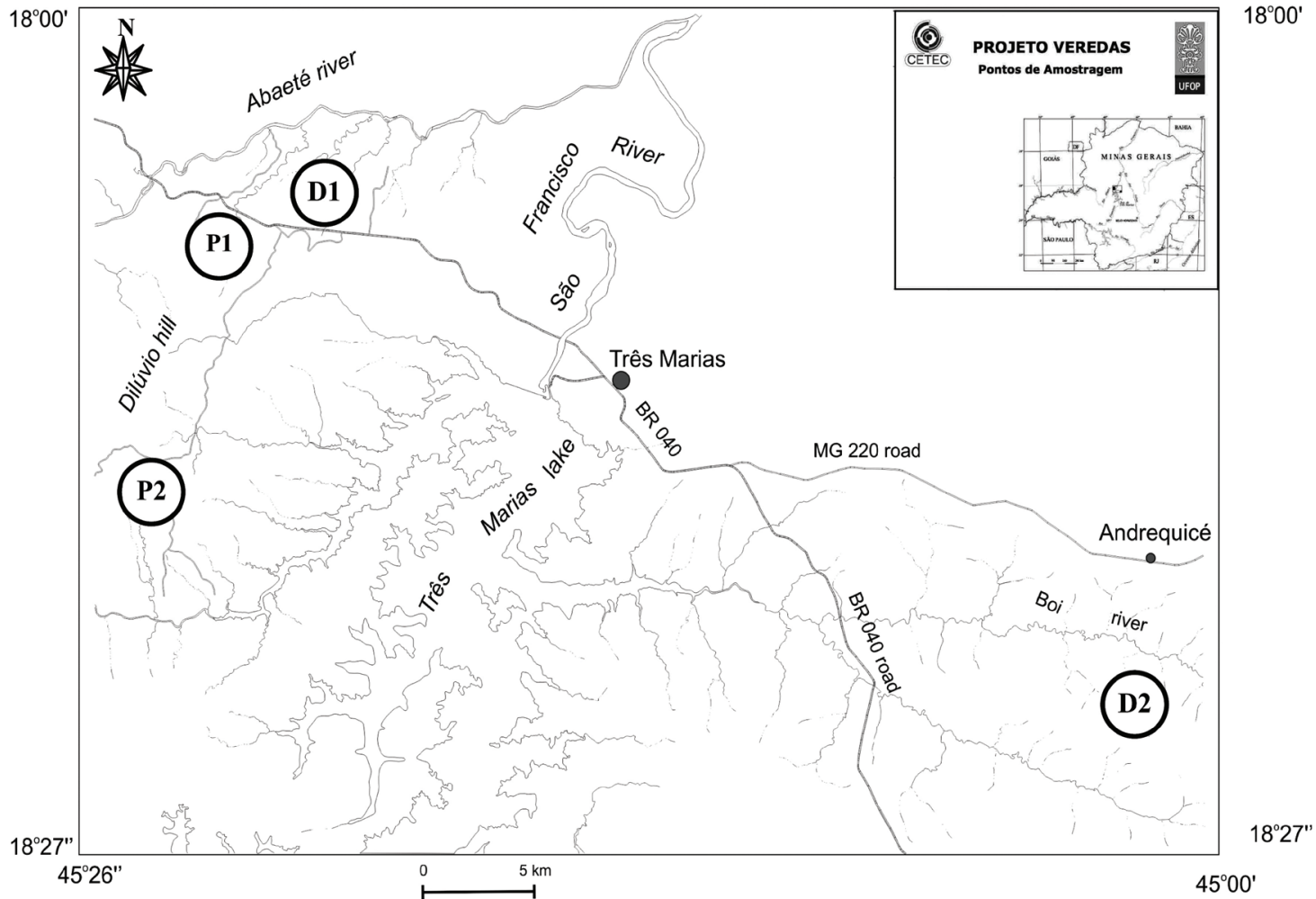

Figure 1. Location of the veredas, near the city of Três Marias. The numbers represent the location of the each vereda, with Vereda P1 and P2 being controls, and Vereda D1 and D2 being planted with eucalypts. Modified from CPRM (2002).

D1 - surrounded by a 3 - year old Eucalyptus plantation) and São José (Vereda D2 - surrounded by a 5 - year old Eucalyptus plantation) (see Figure 2). The sampled veredas location consisted of the following habitats; the wetland area, the adjacent cerrado (for control habitats) and/or Eucalyptus plantation (for modified habitats). In vereda São José (Vereda D2) there was a permanently preserved area of cerrado between the wetland and the Eucalyptus plantation. Each vereda therefore consisted of up to three habitats, these being: $\mathrm{We}$ - wetland zone, under the direct influence of yearly floods; $\mathrm{Ce}$ - cerrado zone, surrounding the wetland; and, if present, Eu-Eucalyptus zone. The Eucalyptus monoculture was planted on areas where the native vegetation was suppressed and the organic soil layer had been tilled into the ground to prepare the soil for planting. The four vereda locations were considered random blocks (habitat zones: wetland + cerrado; wetland + Eucalyptus; wetland + cerrado + Eucalyptus), each habitat having three replicated transects (Figure 2).

\subsection{Ant sampling}

Ant sampling was conducted in May 2010 (dry season) using three methods, namely baits (soil and arboreal), pitfall traps (soil and arboreal), and hand collections. Pairs of $20 \mathrm{~m}$ transects situated $10 \mathrm{~m}$ apart were replicated in three locations in each habitat (see Figure 2). Pitfall traps and baits were placed $5 \mathrm{~m}$ apart along the transect in an alternating fashion. The hand collection was performed for one hour in each habitat. The ground pitfall traps were adapted from the method used by Holway (2005), but traps were left in the ground for three days. Arboreal pitfall traps used the methodology proposed by Majer (1983). The baits followed the method used by Espírito Santo et al. (2012). Sampled ants were sorted and identified to genus level, and then separated into morphospecies or species. The reference collection is stored at the Federal University of Ouro Preto (UFOP), Brazil.

\subsection{Data analysis}

Abundance and ant species richness were calculated for the combined transects pairs using all the information from all sampling methods together. The ant species richness and abundance data were compared by a nested analysis of variance model, testing the effect of 'habitats' (with levels wetland, cerrado and Eucalyptus) nested in 'veredas locations', as random blocks and grouped in a final factor 'conservation' (vereda levels: preserved and disturbed). When necessary, the differences between treatment mean levels were examined using Tukey's post-hoc test.

Non-metric multi-dimensional scaling (NMDS) was performed on ant presence/absence data using the Jaccard similarity measure to produce ordinations of similarity 

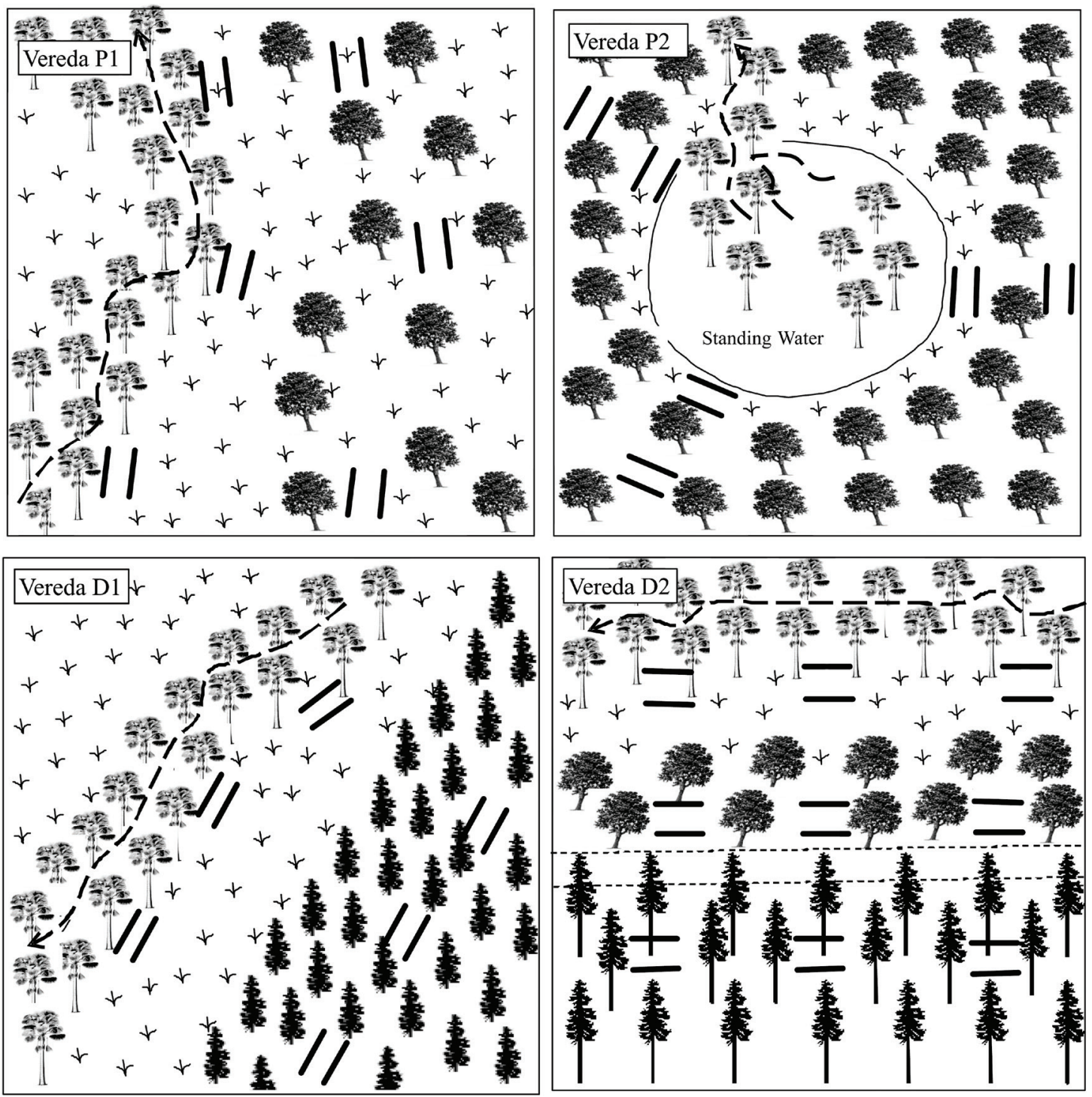

Legend:

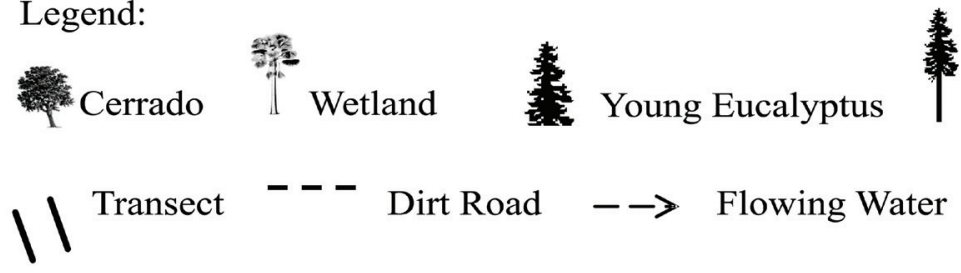

Figure 2. Layout of transects for ant sampling in the veredas, each comprising paired $20 \mathrm{~m}$ transects set of $10 \mathrm{~m}$ apart.

between transects. Wherever it was possible, 'hulls' were constructed on the ordination diagram to delimit outermost boundaries of each vereda location or habitat. Analyses of similarity (ANOSIM - Two Way) tested for significant differences in ant composition for the factor 'habitat' (with levels wetland, cerrado, eucalypt), and the factor 'vereda location' (with each site as levels). Similarity percentages (SIMPER) identified the contribution of ant species to the dissimilarity between the selected factors. The above analyses were performed using Past version 2.04 (Hammer et al., 2001).

\section{Results}

Across all areas 7,575 ants were sampled, belonging to seven subfamilies, 32 genera and 125 species. Of this total, 
$42 \%$ of individuals were sampled in the pristine vereda sites, where five genera and 34 species were exclusive. Besides this, $78.1 \%$ of genera and $46 \%$ of species were common to preserved and disturbed 'veredas locations'. Ant species abundance (from all sampling methods) in each vereda and habitat is shown in Supplementary Table S1.

We sampled two genera and 34 species exclusively in the disturbed "veredas". Myrmicinae and Formicinae were the most speciose subfamilies, with 60 and 30 species, respectively, representing $72 \%$ of the total number of species (see Supplementary Table S1). Pheidole (Myrmicinae) and Camponotus (Formicinae) were the most speciose genera (29 and 24 species, respectively). The most abundant species in these genera were Pheidole sp.19 (414 individuals) and Camponotus crassus (716 individuals), both of which were present in all "veredas". However, the high total abundances were largely influenced by ants with opportunistic behaviour, such as Solenopsis invicta (Myrmicinae), with 1,339 individuals and present in all "veredas". Another pioneer species, with similar opportunistic behaviour, Linepthema humile, was also found in the wetland, as well as the Eucalyptus monoculture.

There was no significant overall difference in ant abundance or species richness among the 'veredas location' (Nested ANOVA abundance, $\mathrm{F}_{(3,18)}=0.050, P=0.98$; Nested ANOVA richness, $\left.\mathrm{F}_{(3 ; 18)}=1.146, P=0.41\right)$. However, there was a significant CPRM (2002) difference between "habitats" (Nested ANOVA, $F_{(5,18)}=5.371, P=0.003$ ), with the wetlands of Vereda D1 and D2 having significantly less ant individuals than the corresponding eucalypt habitat and cerrado of Vereda D2 (see Figure 3a). Although the unbalanced design did not enable us to test the interaction term, the model provided evidence that ant abundance was lower in the impacted wetland than in those that were not surrounded by eucalypt plantations. This trend was reversed in the cerrado habitat, where the highest abundance was in D2 (there was no cerrado in D1). Further, there was an effect of habitat on species richness (Nested ANOVA, $\left.\mathrm{F}_{(5,18)}=3.579, P=0.020\right)$, with all wetlands and eucalypt plantations having lower numbers of species than cerrado, particularly in the cerrado of D2 (see Figure 3b).

The ant species assemblages in Vereda P1, Vereda P2 and Vereda D1 were different from each other, independently of habitats that they comprise (ANOSIM, R $=0.41$, $P<0.0001$; see Figure $4 \mathrm{~b}$ ), but the ant assemblage of Vereda D2 was similar to Vereda P1 (Table S2). The species that most contribute to the separation of the assemblage of the preserved 'veredas location' were Camponotus (Myrmobrachys) sp.1 (3.44\%), Ectatomma brunneum (2\%) and Solenopsis invicta (1.98\%). Pheidole sp.24 $(1.68 \%)$ contribute for the separation of the assemblages in the impacted Vereda D1 and D2, along with Wasmannia auropuctata $(2.03 \%)$ and Ectatomma planidens (1.83\%). Likewise, the wetland, cerrado and eucalypt "habitats" were different, independently of 'veredas location' were they occurred (ANOSIM, R =0.34, $P<0.0001$; see Figure 4a). According to the $\mathrm{R}$ and $p$ values provided by ANOSIM (Table S3), all habitats were significantly different from each other. The species most influential in discriminating the cerrado habitats were Mycocepurus goeldii (1.62\%), Ectatomma planidens (1.56\%), and Pheidole sp.23 (1.52\%). Camponotus rufipes (2.16\%) and Camponotus melanoticus $(2.25 \%)$ had a strong influence in separating wetland habitats, as did Pheidole (Flavens) sp.1 (1.68\%) and Pheidole gertrudae (1.65\%) in eucalypt habitats.

It is worth noting that relative species densities of the most abundant species also seem to reflect habitat conditions (see Table S1). In the Eucalyptus habitat we sampled 54 species from 1,925 individuals, with 49\% of these individuals belonging to the genus Pheidole (952 individuals), and $29 \%$ to Solenopsis invicta (571 individuals). The cerrado and wetland habitats produced 5,633 individuals of ants, belonging to 120 species. Among these species, the most abundant species was Camponotus crassus (688 individuals), Crematogaster torosa (537 individuals) and S. invicta (768 individuals). A further important feature was the high abundance of Atta sexdens ("saúvas") (Myrmicinae) in wetland and
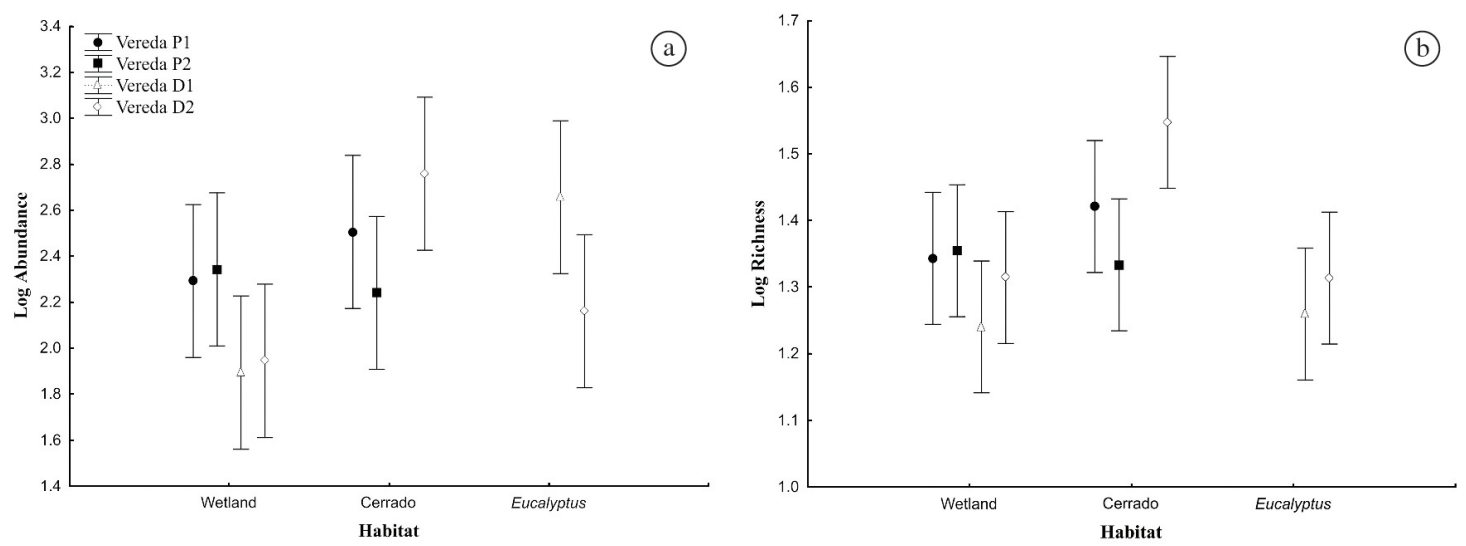

Figure 3. Abundance (a) and richness (b) of ants in habitats for each vereda. Bars are standard deviations. 

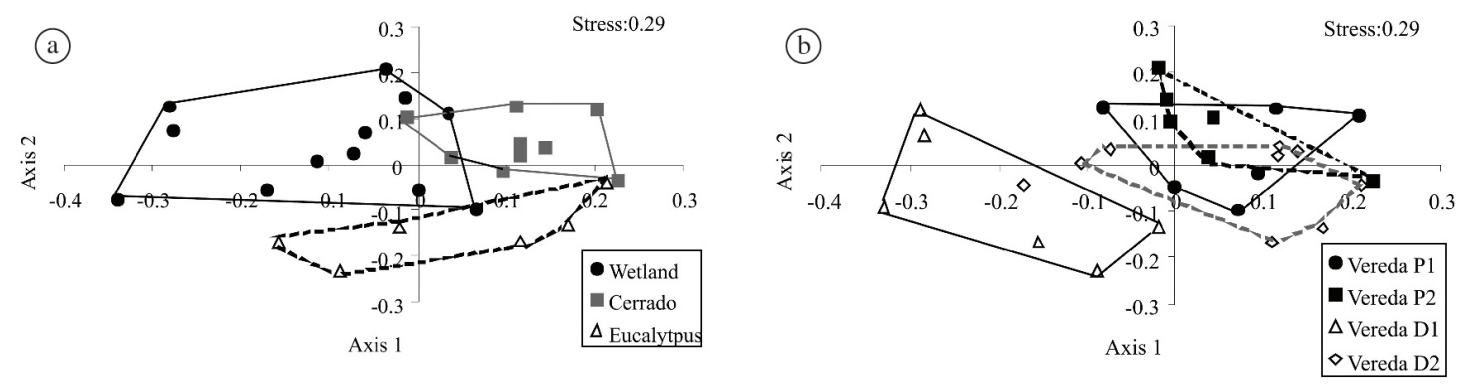

Figure 4. Distribution of (a) habitat and (b) vereda on the NMDS ordination, based on Jaccard similarity measure, using ant presence/absence data. Hulls are drawn around the different habitats in (a) and the veredas in (b).

Table S1. Ant species sampled in the pristine veredas (P) (surrounded by cerrado habitats) and in those impacted by surrounding Eucalyptus plantations (D) (We= wetland; $\mathrm{Ce}=$ cerrado and $\mathrm{Eu}=$ Eucalyptus $)$.

\begin{tabular}{|c|c|c|c|c|c|c|c|c|c|}
\hline \multirow{3}{*}{ Species } & \multicolumn{9}{|c|}{ Areas } \\
\hline & \multicolumn{2}{|c|}{ Vereda P1 } & \multicolumn{2}{|c|}{ Vereda P2 } & \multicolumn{2}{|c|}{ Vereda D1 } & \multicolumn{3}{|c|}{ Vereda D2 } \\
\hline & We & $\mathrm{Ce}$ & We & $\mathrm{Ce}$ & We & Eu & We & $\mathrm{Ce}$ & Eu \\
\hline \multicolumn{10}{|l|}{ Dolichoderinae } \\
\hline Azteca sp.1 & & 6 & & & & & 1 & & \\
\hline Dolichoderus bispinosus Olivier & 1 & & & & & & & & \\
\hline Dolichoderus germaini Emery & & & & & 7 & 3 & 6 & & \\
\hline Dolichoderus lamellosus Mayr & & & & & 1 & & & & \\
\hline Dorymyrmex jheringi Forel & 330 & & 22 & 2 & 16 & 106 & 2 & 1 & 56 \\
\hline Dorymyrmex spurius Santschi & & & 4 & & 12 & 77 & & & \\
\hline Dorymyrmex sp. 1 & & 5 & & & 1 & 31 & & 1 & \\
\hline Dorymyrmex sp. 2 & & & & & & 8 & & & 12 \\
\hline Forelius maranhaoensis Cuezzo & & & & 4 & 1 & & & & \\
\hline Gracilidris pombero Wild and Cuezzo & 2 & & & & & 2 & & 2 & 1 \\
\hline Linepihema anathema Wild & & & & & & & 3 & & \\
\hline Linepithema humile Mayr & 79 & 11 & 1 & & & & 14 & & \\
\hline Linepithema micans Forel & 6 & 3 & 108 & 8 & & & 4 & 1 & \\
\hline Linepithema sp. 1 & & & 55 & & & & & & \\
\hline Linepithema sp.4 & & & 2 & 12 & & & & & \\
\hline \multicolumn{10}{|l|}{ Ecitoninae } \\
\hline Labidus praedator Smith & & & & & & & 5 & & \\
\hline \multicolumn{10}{|l|}{ Ectatomminae } \\
\hline Ectatomma brunneum Smith & 17 & 30 & 11 & & & & 3 & 11 & 5 \\
\hline Ectatomma edentatum Roger & 2 & 1 & & 6 & & & 2 & 11 & 13 \\
\hline Ectatomma lugens Emery & & & & 1 & & & & & \\
\hline Ectatomma opaciventre Roger & & 3 & & & & & & 7 & 7 \\
\hline Ectatomma permagnum Forel & & 2 & & 2 & & & & 4 & 4 \\
\hline Ectatomma planidens Borgmeier & & 32 & 2 & 25 & & & 1 & 28 & 9 \\
\hline Gnamptogenys acuminata Emery & & & & & & 1 & & & \\
\hline Gnamptogenys striatula Mayr & & & & 1 & & & & & \\
\hline \multicolumn{10}{|l|}{ Formicinae } \\
\hline Brachymyrmex sp.1 & 1 & 35 & & & & 9 & 17 & 28 & \\
\hline Brachymyrmex sp. 2 & 1 & & & & & 7 & 1 & & 1 \\
\hline Brachymyrmex sp.3 & 7 & & & & 1 & 1 & & & \\
\hline Brachymyrmex (Pallipes gr.) sp. 4 & & & & 8 & & & & & \\
\hline Brachymyrmex sp.5 & & & & & & 2 & & & \\
\hline Camponotus arboreus Smith & 5 & 12 & & 6 & 1 & & 5 & & \\
\hline Camponotus atriceps Smith & 4 & 10 & & 20 & & 1 & 3 & 15 & 1 \\
\hline
\end{tabular}


Table S1. Continued...

\begin{tabular}{|c|c|c|c|c|c|c|c|c|c|}
\hline \multirow{3}{*}{ Species } & \multicolumn{9}{|c|}{ Areas } \\
\hline & \multicolumn{2}{|c|}{ Vereda P1 } & \multicolumn{2}{|c|}{ Vereda P2 } & \multicolumn{2}{|c|}{ Vereda D1 } & \multicolumn{3}{|c|}{ Vereda D2 } \\
\hline & We & $\mathrm{Ce}$ & We & Ce & We & $\mathbf{E u}$ & We & $\mathrm{Ce}$ & Eu \\
\hline Camponotus blandus Smith & 1 & 137 & & & 1 & 2 & 3 & 6 & 1 \\
\hline Camponotus bonariensis Mayr & & & & & & & & 1 & \\
\hline Camponotus cameranoi Forel & & & & & & & 1 & & \\
\hline Camponotus cingulatus Maur & & 10 & 5 & & & & & 6 & 1 \\
\hline Camponotus crassus Mayr & 31 & 145 & 11 & 37 & 4 & 12 & 39 & 421 & 16 \\
\hline Camponotus leydigi Forel & 2 & & & & & & & 2 & \\
\hline Camponotus melanoticus Emery & 4 & 13 & 3 & 8 & 1 & & 1 & 18 & \\
\hline Camponotus rufipes Fabricius & 12 & 1 & 129 & 20 & 26 & 1 & 26 & & \\
\hline $\begin{array}{l}\text { Camponotus sericeiventris Guérin- } \\
\text { Méneville }\end{array}$ & & & & & & & 1 & & \\
\hline Camponotus trapezoideus Mayr & & & & & & & 1 & & \\
\hline Camponotus (Myrmobrachys gr.) sp.1 & 9 & 60 & 4 & 1 & & 1 & 4 & 81 & 3 \\
\hline Camponotus (Myrmothrix gr.) sp.2 & 2 & 11 & & & & 1 & & 34 & \\
\hline Camponotus (Myrmothrix gr.) sp. 3 & & 2 & & & & & & & \\
\hline Camponotus (Myrmothrix gr.) sp.4 & & & & 1 & 2 & & & & \\
\hline Camponotus sp.13 & & & 1 & & & & 2 & 3 & \\
\hline Camponotus sp.16 & & & & & & & & 1 & \\
\hline Camponotus sp.17 & & & & 1 & & & & & \\
\hline Camponotus sp.19 & & & 3 & & & & & & \\
\hline Camponotus sp. 21 & 4 & & & & & & & & \\
\hline Camponotus sp.22 & & & & & & & 1 & & \\
\hline Camponotus sp.24 & & & & 1 & & & & & 2 \\
\hline Camponotus sp. 25 & & & & & 1 & & & & \\
\hline Nylanderia nr. fulva Mayr & 9 & & & & & & & & \\
\hline Myrmicinae & & & & & & & & & \\
\hline Acromyrmex balzani Emery & & 1 & 1 & 1 & & & 1 & 13 & 1 \\
\hline Apterostigma sp.1 & & & & 1 & & & & 1 & \\
\hline Apterostigma (Pilosum gr.) sp.1 & & & 1 & & & & & & \\
\hline Atta laevigata Smith & & & 1 & & & & & & \\
\hline Atta sexdens Linneaus & 99 & & 24 & 199 & & & & 68 & \\
\hline Cephalotes atratus Lineaus & & & & 25 & & & & & \\
\hline Cephalotes borgmeieri Kempf & & & & 3 & & & & & \\
\hline Cephalotes eduarduli Forel & 1 & 15 & & & & & & & \\
\hline Cephalotes maculatus Smith F. & & 3 & & & 1 & & 1 & 1 & \\
\hline Cephalotes pusillus Klug & & 8 & 2 & 11 & 57 & & 2 & 2 & \\
\hline Crematogaster acuta Fabricius & 14 & & 2 & & 158 & 14 & 18 & & \\
\hline Crematogaster limata Smith F. & 3 & & & & & & 1 & & 2 \\
\hline Crematogaster torosa Mayr & 10 & 316 & 1 & & & & & 210 & \\
\hline Crematogaster nr. obscurata Emery & & 38 & 1 & 3 & & & & & \\
\hline Crematogaster sp.1 & & & 1 & & & & & & \\
\hline Cyphomyrmex rimosus Spinola & & & 2 & & 2 & & 1 & 1 & \\
\hline Megalomyrmex sp.1 & & & 1 & & & & & & \\
\hline Mycocepurus goeldii Forel & 2 & 4 & & 4 & & 1 & & 5 & 8 \\
\hline Mycocepurus smithii Forel & & & & & & & & 3 & \\
\hline Myrmicocrypta sp.1 & & 1 & & & & & & 3 & \\
\hline Pheidole gertrudae Forel & 117 & & & & & 287 & & & 1 \\
\hline Pheidole (Flavens gr.) sp.1 & & 8 & & 27 & 1 & 2 & & 15 & 27 \\
\hline Pheidole (Flavens gr.) sp. 3 & 1 & 6 & & & & & & & 5 \\
\hline Pheidole sp.6 & & & 1 & & 2 & & & 12 & \\
\hline
\end{tabular}


Table S1. Continued...

\begin{tabular}{|c|c|c|c|c|c|c|c|c|c|}
\hline \multirow{3}{*}{ Species } & \multicolumn{9}{|c|}{ Areas } \\
\hline & \multicolumn{2}{|c|}{ Vereda P1 } & \multicolumn{2}{|c|}{ Vereda P2 } & \multicolumn{2}{|c|}{ Vereda D1 } & \multicolumn{3}{|c|}{ Vereda D2 } \\
\hline & We & $\mathrm{Ce}$ & We & $\mathrm{Ce}$ & We & $\mathbf{E u}$ & We & $\mathrm{Ce}$ & Eu \\
\hline Pheidole sp.19 & 2 & 6 & & 18 & 4 & 324 & 6 & 22 & 32 \\
\hline Pheidole sp.20 & & & & 2 & & & & & \\
\hline Pheidole sp.21 & & 1 & 2 & & & & & & \\
\hline Pheidole sp.22 & 4 & 4 & 4 & & & & & 7 & 9 \\
\hline Pheidole sp.23 & & 5 & 15 & 13 & & 1 & 1 & 23 & 1 \\
\hline Pheidole sp.24 & 47 & 33 & 4 & 15 & & 1 & 15 & 13 & 186 \\
\hline Pheidole sp.25 & 9 & & 2 & & 1 & & & & \\
\hline Pheidole sp.26 & 3 & & 1 & & & 1 & & 6 & 25 \\
\hline Pheidole sp.27 & & 3 & & & & & & 21 & \\
\hline Pheidole sp.28 & & & & & 2 & 1 & 17 & & \\
\hline Pheidole sp.29 & & & & & & & & 5 & \\
\hline Pheidole sp.30 & & & & & 1 & & & & 29 \\
\hline Pheidole sp.31 & & & & & & & & 2 & 9 \\
\hline Pheidole sp.32 & & & & & 2 & & & & \\
\hline Pheidole sp.33 & & & & & 1 & & & 3 & 4 \\
\hline Pheidole sp.34 & & & & & & & & 7 & 1 \\
\hline Pheidole sp.35 & & & & & 3 & & & 1 & \\
\hline Pheidole sp.36 & & & & & 4 & & & & \\
\hline Pheidole sp.37 & & & & & & & & & 6 \\
\hline Pheidole sp.40 & & & & & & & & 1 & \\
\hline Pheidole sp.43 & & 1 & & 18 & & & & 30 & \\
\hline Pheidole sp.45 & 9 & 18 & 1 & & 1 & & & 9 & \\
\hline Pheidole sp.46 & & 4 & 1 & & & & & & \\
\hline Pheidole sp.47 & 1 & & & & & & & & \\
\hline Pheidole sp.48 & & 1 & & 1 & 2 & & & & \\
\hline Pogonomyrmex naegelii Emery & & & & & & 1 & 1 & & \\
\hline Sericomyrmex parvulus Forel & 1 & & & & & & & & \\
\hline Solenopsis invicta Buren & 2 & & 179 & 18 & & 570 & & 569 & 1 \\
\hline Solenopsis (Geminata gr.) sp.1 & & 2 & 1 & & & 1 & & & \\
\hline Solenopsis sp.1 & & & 34 & & & 4 & 1 & 2 & \\
\hline Trachymyrmex dichrous Kempf & & & & & & & & 1 & \\
\hline Trachymyrmex fuscus Emery & & 2 & & & & & & & \\
\hline Trachymyrmex sp.1 & & & & & & & & 3 & 1 \\
\hline Wasmannia auropunctata Roger & 26 & & 1 & 24 & 2 & & 14 & 36 & 25 \\
\hline Wasmannia rochai Forel & & & & & & & & 20 & \\
\hline Xenomyrmex sp.1 & & & & 19 & & & & & \\
\hline Ponerinae & & & & & & & & & \\
\hline Hypoponera sp.4 & & & 1 & & & & & & \\
\hline Odontomachus haematodus Emery & 1 & & & 1 & 1 & & & & \\
\hline Odontomachus meinerti Forel & & & & & & & 2 & & 1 \\
\hline Pachycondyla ferruginea Smith & 1 & & & & & & & & \\
\hline Pachycondyla obscuricornis Emery & 5 & & & & 3 & 3 & 6 & & \\
\hline Pseudomyrmecinae & & & & & & & & & \\
\hline Pseudomyrmex acanthobius Emery & 1 & & 48 & & 2 & & 1 & & \\
\hline Pseudomyrmex termitarius Smith & & 3 & & & 2 & & & & \\
\hline Pseudomyrmex nr. urbanus Smith & & 1 & & & 1 & & & & 1 \\
\hline Pseudomyrmex oculatus gr. sp.1 & & & & & & & & & 1 \\
\hline Pseudomyrmex sp.2 & & 1 & & & & & & & \\
\hline Pseudomyrmex sp.3 & & & & & & & 2 & & \\
\hline
\end{tabular}


Table S2. Comparison of the variation of similarities (ANOSIM of ant species composition among the four veredas studied.

\begin{tabular}{ccccc}
\hline P - values & Vereda P1 & Vereda P2 & Vereda D1 & Vereda D2 \\
\hline Vereda P1 & 0 & 0.0031 & 0.0016 & 0.0871 \\
Vereda P2 & 0.0031 & 0 & 0.0022 & 0.0473 \\
Vereda D1 & 0.0016 & 0.0022 & 0 & 0.0019 \\
Vereda D2 & 0.0871 & 0.0473 & 0.0019 & 0 \\
& & & & Vereda D2 \\
\hline R - values & Vereda P1 & Vereda P2 & Vereda D1 & 0.1565 \\
Vereda P1 & 0 & 0.5444 & 0.675 & 0.2128 \\
Vereda P2 & 0.5444 & 0 & 0.6444 & 0.5214 \\
Vereda D1 & 0.675 & 0.6444 & 0 & 0 \\
Vereda D2 & 0.1565 & 0.2128 & 0.5214 & \\
\hline
\end{tabular}

Table S3. Comparison of the variation of similarities (ANOSIM of ant species composition among the three habitats studied.

\begin{tabular}{lccc}
\hline $\mathbf{P}-$ values & Wetland & Cerrado & Eucalyptus \\
\hline Wetland & 0 & 0.0018 & 0.0017 \\
Cerrado & 0.0018 & 0 & 0.0003 \\
Eucalyptus & 0.0017 & 0.0003 & 0
\end{tabular}

\begin{tabular}{lccc}
\hline $\mathbf{R}$ - values & Wetland & Cerrado & Eucalyptus \\
\hline Wetland & 0 & 0.5444 & 0.675 \\
Cerrado & 0.5444 & 0 & 0.6444 \\
Eucalyptus & 0.675 & 0.6444 & 0 \\
\hline
\end{tabular}

cerrado of the Veredas P1 and P2. Atta sexdens was absent in the Eucalyptus habitat.

\section{Discussion}

The present study suggests that the ant assemblage is characterised by habitat type, and the ant fauna of the cerrado is resilient to surrounding impacts in terms of species richness but not species composition or relative abundance, thus partially corroborating our hypothesis prediction. The "veredas" are ecosystems under the influence of seasonal water flooding, and they support a unique plant community, based on endemic species such as the Buriti, which has a strong engineering role in the ecosystem. After the Buriti has become established in the area, several other tree and shrub species are able to colonise the flooded margins and stabilise and enrich the soil, creating conditions for further succession, along with the retention of moisture (Rizzini, 1997). The ground and arboreal ant fauna of these "veredas" is directly linked to the phenomena of flooding, the stratification of vegetation, geomorphological evolution and colonisation by other invertebrates. Therefore, ant species responses to habitats may be related to how these habitats evolved and how they are preserved.

Eucalyptus monocultures are poor environments in terms of spatial heterogeneity and species diversity, and they exhibit simplified nutrient cycling and energy dynamics. Such conditions may contribute to reduced numbers of ant species in these environments (Vallejo et al., 1987) and reduce the occurrence of specialist species (Pacheco et al., 2009). The ant species that colonise the area after impact were more aggressive types, and could banish or eliminate the resident species. With all the impact caused by the preparation for the planting of Eucalyptus, some rare species or specific habitats may also be eliminated. Accordingly, we found that the diversity of ants in Eucalyptus was lower than in pristine habitats, but most species found in Eucalyptus were also observed at least somewhere in the cerrado and wetland. This suggests that the preservation of areas surrounded by the plantations may favour the colonisation of ants in environments with low structural complexity, as is the case with the Eucalyptus plantation.

Our findings contrast with our predictions that opportunistic and invasive species would dominate in the Eucalyptus, forming a completely distinct animal community, and therefore highlight the importance of the legal "Permanent Preservation Areas" attached to each vereda. Besides acting as a source of species that colonise the agro-ecological habitats, such pristine vereda habitats also promote the flow of matter and energy between these environments. The "veredas" are true ecological corridors, functioning as a biological stock, and promoting colonisation of disturbed areas where native vegetation is scarce. On the other hand, the widespread presence of S. invicta in the natural habitats of veredas reflects the opposite of this exchange phenomenon, representing decreasing quality of the wetlands and cerrado.

Another interesting indicator of habitat structure dependence was Atta sexdens in the surrounding cerrado of Vereda P2. Costa et al. (2010) reported that Atta species nests require good, and well-preserved, soil conditions, but are resistant to surrounding impacts, as long as new leaves of pioneer plants are available. More recent works have shown that Attini species are positive engineers of forest biodiversity, and are related to high seed dispersal and seedling survivorship (Leal et al., 2007; Silva et al., 2007; Wirth et al., 2007). Members of the tribe Attini, in particular the genera Atta and Acromyrmex, have been reported as being abundant in Eucalyptus monocultures (Araújo et al., 1997; Cantarelli, 2005), but this was not observed in this study. Due to high leaf concentrations of 
tannins and other deterrent compounds in Eucalyptus, it is an unfavourable habitat for these genera to nest or forage. Indeed, these genera forage in monoculture habitats only in the initial stages, when the native vegetation has just been removed for planting (Bento and Della Lucia, 1993).

It is worth noting that both wetlands and cerrados contained species requiring high quality of arboreal habitats, thus reflecting some resilience and resistance of these ecosystems to the impact of being surrounded by Eucalyptus. The presence of certain genera supports this perception, as exemplified by species in cerrado such as Mycocepurus goeldii (which nests in soil with rotten logs, and which takes feces of insects, fruit pulp and seeds to grow its fungal gardens - Pizo and Oliveira (2000); Araújo et al. (2002)), and Ectatomma planidens plus E. brunneum (both aggressive and generalist predators of other arthropods, or scavengers - Silvestre et al. (2003)). Another noteworthy finding in the cerrado habitat (Vereda P2) was a new, as yet undescribed, species of Xenomyrmex (Forel 1885). The biology of this genus is little known, but Wheeler and Wheeler (1960) report that this genus builds its colony in tree cavities and suggest that these ants may not be restricted to the trunks of trees, but rather descend to the ground in search of food.

Such woody habitat conditions are part of the wetland ecosystems, and apparently could also be related to the presence of species such Camponotus rufipes and C. melanoticus. Both species are typical of Brazilian savanna, nesting on the ground or under leaves and are generalist foragers (Silvestre et al., 2003); they were found in both pristine and impacted "veredas". In our study, both species were confined to wetland and cerrado habitats, indicating that the eucalypt habitat doesn't provide conditions for nesting and foraging. Likewise, army ants of the species Labidus praedator were only found in the wetland of Vereda D2, reflecting the availability of considerable amounts of invertebrate resources to sustain their vagile colonies. On the other hand, "veredas" have both high availability of food resources and nesting sites, and have proved to be susceptible to establishment by opportunistic species, such as $S$. invicta, L. humile and Wasmannia auropunctata. These ants have polygynous colonies, territorial, aggressive behaviour and exhibit generalist foraging on the soil and trees. This type of niche promotes rapid colonisation of the environment, with interconnected nests leading to a supercolony of cooperative workers, especially after an environmental disturbance. Once established, colonies displace other species of ants and arthropods, resulting in a general decrease in species richness and abundance (Delabie, 1988; Diehl-Fleig, 2006).

The presence of S. invicta in cerrado of Vereda P2 may indicate the presence of secondary impacts in this vereda, such as cattle or other human activities. However, its presence in the cerrado of Vereda D2 indicates that the disturbances could be caused by nearby Eucalyptus monoculture areas. The abundance of S. invicta at higher levels than that of $W$. auropunctata and L. humile in these areas and in the eucalypt habitat of Vereda D1, suggests that $S$. invicta is the ant dominating in this habitat.

The present work is the first large ant survey in the vereda ecosystems, and is the first to provide the background for designing bioindication protocols for diagnosis of the conservation status of these complex wetland habitats within the Brazilian Cerrado. An example of their use is the impact on ant species composition and assemblage structure caused by the plantation. For instance, the number of edaphic ant species in the wetland soils of the "veredas" surrounded by Eucalyptus was lower than in the preserved areas. Such species composition suggests an accelerated succession towards a drier ecosystem due to ground water drawdown caused by the monoculture. Based on geomorphologic data, such succession should be happening faster in some of the preserved areas instead. Hence, changes in the distribution of ant species among functional guilds appears to reflect differences in the soil's capacity for water retention, along with variation in micro-spaces between grains in the soil and sediment, and vegetation changes caused by human impacts (CB. CostaMilanez, unpublished data). This supports the hypothesis that ant assemblages are a sensitive community component, which is potentially a good candidate for bioindication of early impacts caused by land use change.

Acknowledgements - We thank Roberth Fagundes for help with the statistical analysis. Filipe Paixão and Edgar Silva were particularly helpful in the field. Financial support for CB Costa-Milanez was provided by the Conselho Nacional de Desenvolvimento Científico e Tecnológico, CNPq and Fundação de Amparo à Pesquisa do Estado de Minas Gerais (FAPEMIG). SP Ribeiro and PTA Castro are also recipients of CNPq research grants. Rodrigo Feitosa for the ants identification.

\section{References}

ALENCAR-SILVA, T. and MAILLARD, P.,2007. Delimitação e caracterização do ambiente de vereda: I. O potencial das imagens RADARSAT-1. In Anais XIII Simpósio Brasileiro de Sensoriamento Remoto, 2007. Florianópolis: INPE. p. 4751-4758.

ARAÚJO, MS., DELLA LUCIA, TMC. and MAYHÉ-NUNES, AJ., 1997. Levantamento de Attini (Hymenoptera, Formicidae) em povoamento de Eucalyptus na região de Paraopeba, Minas Gerais, Brasil. Revista Brasileira de Zoologia, vol. 14, no. 2, p. 323-328. http://dx.doi.org/10.1590/S0101-81751997000200006.

-., 2002. Caracterização de ninhos e atividade forrageadora de Trachymyrmex fuscus Emery (Hymenoptera, Formicidae) em plantio de eucalipto. Revista Brasileira de Zoologia, vol. 19, no. 2, p. 419-427. http://dx.doi.org/10.1590/S0101-81752002000200008.

BENTO, JMS. and DELLA LUCIA, TMC., 1993. Acabar com a saúva sem acabar com o Brasil. Ciência Hoje, vol. 15, no. 90, p. $48-49$.

CANTARELLI,EB.,2005. Silvicultura de precisão no monitoramento e controle de formigas cortadeiras em plantios de Pinus. Universidade Federal de Santa Maria. 125 p. PhD Thesis. 
Companhia de Pesquisa de Recursos Minerais - CPRM, 2002. Programa Levantamentos Geológicos Básicos do Brasil: Folha Três Mais. Brasília: Governo Federal CPRM - Serviço Geológico do Brasil; Ministério de Minas e Energia - MME; Secretaria de Minas e Metalurgia; Governo de Minas Gerais; Secretaria de Estado de Minas e Energia - SEME; Companhia Mineradora de Minas Gerais - COMIG.

COSTA, CB., RIBEIRO, SP. and CASTRO, PTA., 2010. Ants as bioindicators of a natural succession in savanna and riparian vegetation impacted by dreging in the Jequitinhonha River Basin, Brazil. Restoration Ecology, vol. 18, no. 1, p. 148-157.

COUTINHO, HLC., UZÊDA, MC., ANDRADE, AG. and TAVARES, SRL., 2003. Ecologia e biodiversidade do solo no contexto da Agroecologia. Informe Agropecuário, vol. 24, no. 220, p. 45-54.

DELABIE, JHC., 1988. Ocorrência de Wasmannia auropunctata (Roger, 1963) (Hymenoptera, Formicidae, Myrmicinae) em cacauais na Bahia, Brasil. Revista Theobroma, vol. 18, no. 1, p. 29-37.

DIEHL-FLEIG, E., 2006. Formigas invasoras: O caso da formiga argentina Linepithema humile (Mayr 1868). Acta Biológica Leopondensia, vol. 28, no. 1, p. 5-9.

EITEN, G.,1994. Vegetação do Cerrado. In PINTO, MN. Cerrado: Caracterização, Ocupação e Perspectivas. Brasília: Editora Universidade de Brasília. p. 17-73.

ESPÍRITO SANTO, NB., RIBEIRO, SP. and LOPES, JFS., 2012. Evidence of competition between two canopy ant species: Is aggressive behavior innate or shaped by a competitive environment? Psyche, vol. 2012, p. 1-8. http://dx.doi.org/10.1155/2012/609106.

HOLWAY, DA., 2005. Edge effects of an invasive species across a natural ecological boundary. Biological Conservation, vol. 121, p. 561-567. http://dx.doi.org/10.1016/j.biocon.2004.06.005.

HAMMER, O., HARPER, DAT. and RYAN, PD., 2001. PAST: Paleontological statistics software package for education and data analysis. Palaeontologia Electronica, vol. 4, p. 9.

LAVELLE, P., DECAËNS, T., AUBERT, M., BAROT, S., BLOUIN, M., BUREAU, F., MARGERIE, F., MORA, P. and ROSSI, JP., 2006. Soil invertebrates and ecosystem services. European Journal of Soil Biology, vol. 42, p. 3-15. http://dx.doi. org/10.1016/j.ejsobi.2006.10.002.

LEAL, I.R., WIRTH, R. and TABARELL, M., 2007. Seed dispersal by ants in the semi-arid Caatinga of north-east Brazil. Annals of Botany, vol. 99, no. 5, p. 885-894. PMid:17430980 PMCid:PMC2802904. http://dx.doi.org/10.1093/aob/mcm017

MAJER, JD., 1983. Ants bioindicators of minesite rehabilitation, land use and land conservation. Environmental Management, vol. 4 , no. 7 , p. $375-383$.

MAJER, JD. and DELABIE, JHC., 1994. Comparison of the ant communities of annually inundated and terra firme forests at Trombetas in the Brazilian Amazon. Insectes Sociaux, vol. 41, p. 343-359. http://dx.doi.org/10.1007/BF01240639.

MAJER, JD., ORABI, G. and BISEVAC, L., 2007. Ants (Hymenoptera: Formicidae) pass the bioindicator scorecard. Myrmecological News, vol. 10, p. 69-76.

MARINHO, CGS., ZANETTI, R., DELABIE, JHC., SCHLINDWEIN, MN. and RAMOS, LS., 2002. Diversidade de formigas (Hymenoptera: Formicidae) da serrapilheira em eucaliptais (Myrtaceae) e área de cerrado de Minas Gerais. Neotropical Entomology, vol. 2, no. 31, p. 187-195.
MENTONE, TO., DINIZ, EA., MUNHAE, CB., BUENO, OC. and MORINI, MSC., 2011. Composição da fauna de formigas (Hymenoptera: Formicidae) de serapilheira em florestas semidecídua e de Eucaliptus spp., na região sudeste do Brasil. Biota Neotropica, vol. 11, no. 2, p. 1-10.

OLIVEIRA,NLS. and FERREIRA, I.M.,2007. Análise ambiental das veredas do chapadão de Catalão (GO). In Anais do X EREGEO Simpósio Regional de Geografia - Abordagens Geográficas do Cerrado: paisagens e diversidades, 2007. Catalão: Universidade Federal de Goiás. p. 1-16.

OLIVEIRA-FILHO,EC. and LIMA, J.E.F.W.,2002. Potencial de impacto da agricultura sobre os recursos hídricos na região do cerrado. Embrapa. 50 p. Documentos, no. 56.

PACHECO, R., SILVA, RR., MORINI, MSC. and BRANDÃO, RF., 2009. A comparison of the leaf-litter ant fauna in a secondary Atlantic Forest with an adjacent pine plantation in Southeastern Brazil. Neotropical Entomology, vol. 38, p. 55-65. http://dx.doi. org/10.1590/S1519-566X2009000100005.

PIZO, MA. and OLIVEIRA, PS., 2000. The use of fruits and seeds by ants in the Atlantic Forest of Southeast Brazil. Biotropica, vol. 32, no. 4, p. 851-861. http://dx.doi.org/10.1646/00063606(2000)032[0851:TUOFAS]2.0.CO;2.

RIZZINI,CT.,1997. Tratado de Fitogeografia do Brasil: Aspectos ecológicos, sociológicos e florísticos. 2. ed. Rio de Janeiro: Âmbito Cultural Edições Ltda. 747 p.

SILVA, PD., LEAL, IR., WIRTH, R. and TABARELLI, M., 2007. Harvesting of Protium heptaphyllum (Aubl.) March. seeds (Burseraceae) by the leaf-cutting ant Atta sexdens L. promotes seed aggregation and seedling mortality. Revista Brasileira de Botânica, vol. 30, no. 3, p. 553-560.

SILVESTRE, R., BRANDÃO, CRF. and ROSA DA SILVA, R.,2003. Grupos funcionales de hormigas: El caso de los gremios del Cerrado. In FERNÁNDEZ, F. Introcción a lãs hormigas de La región Neotropical. Bogotá: Instituto de Investigación de Recursos Biológicos Alexander Von Humboldt. p. 113-148.

TAVARES, AA., BISPO, PC. and ZANZINI, A., 2008. Efeito do turno de coleta sobre comunidades de formigas epigéicas (Hymenoptera: Formicidae) em áreas de Eucalyptus cloeziana e de Cerrado. Neotropical Entomology, vol. 37, no. 2, p. 126-130. PMid:18506289. http://dx.doi.org/10.1590/S1519-566X2008000200003.

VALLEJO, LR., FONSECA, CL. and GONÇALVES, DRP., 1987. Estudo comparativo da mesofauna do solo em áreas de Eucaliptus citriodora e mata secundária heterogênea. Revista Brasileira de Biologia, vol. 47, p. 363-370.

VEZZANI, FM., TEDESCO, MJ. and BARROS, NF., 2001. Alterações dos nutrientes no solo e nas plantas em consórcio de eucalipto e acácia negra. Revista Brasileira de Ciencia do Solo, vol. 25, p. 225-231.

VITAL, MHF., 2007. Impacto ambiental de florestas de eucalipto. Revista do BNDES, vol. 14, no. 28, p. 235-276.

WHEELER,GC. and WHEELER, J.,1960. Supplementary studies on the larvae of the Myrmicinae (Hymenoptera: Formicidae). In Proceedings of the Entomological Society of Washington, 1960. Grand Forks: University of North Dakota. vol. 62, p. 1-32.

WIRTH, R., MEYER, S.T., ALMEIDA, W.R., ARAUJO, MV. Jr, BARBOSA, V.S. and LEAL, I.R., 2007. Increasing densities of leaf-cutting ants (Atta spp.) with proximity to the edge in a Brazilian Atlantic forest. Journal of Tropical Ecology, vol. 23, p. 501-505. http://dx.doi.org/10.1017/S0266467407004221. 